\title{
EU-SILC: Should We Make Do with What We Have?
}

\author{
Marietta E.A. Haffner \\ OTB - Research for the Built Environment, Faculty of Architecture and the Built \\ Environment, Delft University of Technology \\ m.e.a.haffner@tudelft.nl
}

School of Global, Urban \& Social Studies, RMIT University, Melbourne, Australia, marietta.haffner@rmit.edu.au

Cambridge Centre for Housing \& Planning Research, Department of Land Economy, Cambridge, UK

\begin{abstract}
In this Briefing Paper the focus is on the EU-SILC and on the questions: What are the strengths and weaknesses of the pan-European data set EU-SILC, which stands for 'European Union Statistics of Income and Living Conditions'? How useful is this database when making international housing comparisons? The examples in this paper are based on my experience with the EU-SILC and explore a number of themes such as setting universal norms for all countries and differences in data requirements between housing and poverty research. My conclusion is that some of these topics transcend the database evaluation and are concerned with the definition of concepts. As long as there are no 'better' data alternatives, we need to make do with what we have, but should do so carefully and transparently.
\end{abstract}

Keywords: Affordability, Housing, Imputed rent, Deprivation, Overcrowding, Residual income. 


\section{Introduction}

This short Briefing Paper, written by invitation of the editor, examines a couple of strengths and weaknesses of a pan-European data set, the EU-SILC, which is the abbreviation for the dataset entitled European Union Statistics of Income and Living Conditions. The dataset is the main instrument in the EU to monitor the development in income, poverty, social exclusion and living conditions and has been updated annually since 2003. ${ }^{1}$ Reliance on the EU-SILC does not mean that the EU-SILC data and methodology are not the subject of discussion or changes in time (European Commission, 2009). In the abundance of literature available almost 190,000 hits in Google for EU-SILC on 2 November 2015 - there is also criticism of the basic variables of the EU-SILC, such as income measurement. Krell et al. (2015: 22; see also Iacovou et al., 2012) report on the inconsistency between cross-sectional and longitudinal income data in EU-SILC and warn: 'users of EU-SILC should be aware of the data limitations when conducting income analyses'. These inconsistencies are reflected across time in the measures that are derived from income as well, such as the measures of inequality and poverty - for example, the EU-SILC key outcome variable 'people at risk of poverty'.

This Briefing Paper, however, is not about poverty and the discussions linked to poverty, and it accepts the following basic premise: 'It is beyond question that EU-SILC is a highly valuable data source for social and economic research in Europe.' (Krell et al., 2015: 22). This paper aims to discuss whether the database is useful for making international comparisons in the field of housing. These observations are based on my experience with this dataset. ${ }^{3}$ Even though EU-SILC is not construed as a housing database, housing may impact social exclusion and poverty. 'Housing costs constitute the most important and most direct impact of housing on poverty and material deprivation' (Tunstall et al., 2013: 5). Housing affordability is indeed a topic covered by the EU-SILC, as are some data relating to the quality/comfort of living for example, housing deprivation and overcrowding. I will limit my observations to these three housing indicators, which can be accessed in the "main tables" ${ }^{4}$ containing the main indicators produced with EU-SILC. The definitions of these variables are available in the Living Conditions Glossary on the Eurostat website. ${ }^{5}$

\section{Housing deprivation and overcrowding}

Among its set of indicators on material deprivation Eurostat lists housing deprivation, which is defined as the percentage of the population deprived of each available housing deprivation item. The items considered are:

- leaking roof, damp walls/floors/foundation, or rot in window frames or floor;

- lack of bath or shower in the dwelling;

- lack of indoor flushing toilet for sole use of the household;

\footnotetext{
1 http://ec.europa.eu/eurostat/web/microdata/european-union-statistics-on-income-and-living-conditions (1 November 2015). The Lisbon Strategy (2000-2010) was followed by the Europe 2020 Strategy in the fight against poverty (European Council, 2010).

${ }^{2}$ The share of persons in a country whose disposable income is less than $60 \%$ of the national equivalent median income after social transfers. Equivalent implies that income is corrected for the composition of the household.

${ }^{3}$ Haffner and Dol (2011); Haffner et al. (2012a, 2012b); Haffner and Ras (2015).

${ }^{4} \mathrm{http}$ ://ec.europa.eu/eurostat/web/income-and-living-conditions/data/main-tables (1 November 2015).

5 http://ec.europa.eu/eurostat/statistics-explained/index.php/Category:Living_conditions_glossary (16 December 2015)
} 
- problems with the dwelling: too dark, not enough light.

In the field of living conditions, one of the indicators is the rate of overcrowding. This indicator is defined as the percentage of the population living in an overcrowded household. A person is considered as living in an overcrowded household if the household does not have at its disposal a minimum number of rooms equal to:

- one room for the household;

- one room per couple in the household;

- one room for each single person aged 18 and over;

- one room per pair of single people of the same sex between 12 and 17 years of age;

- one room for each single person between 12 and 17 years of age and not included in the previous category;

- one room per pair of children under 12 years of age.

As with the $60 \%$ poverty line, these norms are set for all countries, and the question is whether a normative standpoint is logical here. Is dwelling space in the case of overcrowding a norm put forward by advanced European economies? Sunega (2014) concluded earlier in this journal that a shortage of dwelling space in advanced economies is subjectively rated ${ }^{6}$ higher than the objective rate of overcrowding and vice versa for post-socialist countries. Another option may be, as Haffner and Ras (2015) showed, to relate these types of variables to overall satisfaction with the dwelling and the neighbourhood, a variable that has been available for several years from the ad hoc housing module. ${ }^{7}$

Considering Burns and Grebler's finding (1977) referred to by Mayo et al. (1986), there may be an underling factor, such as derived demand, that will increase when a country's income increases (up to a point), which will then stimulate investment in housing. Stephens et al. (2010: 13) report that expectations about housing quality go hand in hand with the economic growth of countries. Haffner et al. (2012b) illustrate a highly positive correlation between GDP per capita and the share of tenants without at least one housing problem (EU-SILC 2007). Haffner and Ras (2015) found a similar outcome between equivalised household disposable income and absence of housing problems (EU-SILC 2012). Do these types of results therefore require different norms for different countries that are adapted to changes in time?

Palvarani \& Pavolini (2010: 140) suggest considering the contrasting option of using fewer problems as indication of problems, and propose considering 'the types of deprivation most rarely found in the population as the most severe and the most widespread types as the least severe'. If people compare themselves against the 'usual' surroundings in their country, the 'subjective' difference between low-income or poor and other or non-poor people in a country might be a more useful indicator than the EU-SILC norm that is being used, even if it is based on the best intentions, namely, to ensure that housing is of sufficient quality and offers enough space for everyone in the long term in order to diminish poverty.

\footnotetext{
${ }^{6}$ This is also a variable available in EU-SILC, but not in the main tables.

${ }^{7} \mathrm{http}$ ://ec.europa.eu/eurostat/web/income-and-living-conditions/data/ad-hoc-modules (1 November 2015).
} 


\section{Critical Housing Analysis}

\section{Housing costs}

In the set of data on living conditions, the housing cost burden or overburden is listed. This indicator is defined as the percentage of the population living in a household where the total housing costs (net of housing allowances) represent more than $40 \%$ of the total disposable household income (net of housing allowances). The indicator aims to measure the unaffordability of housing and can be better described as the 'at-risk-of' unaffordability indicator. It shows that, since $2005,11 \%$ of people in the EU have been spending more than $40 \%$ of their income on rent, mortgage interest, maintenance and energy. ${ }^{8}$ Apart from a number of methodological issues with the EU-SILC, there are conceptual issues that partly go beyond the EU-SILC.

\section{Methodological issues}

One of the methodological issues has been called a reference period mismatch by Iacovou et al. (2012). Income is usually from the year 'before', while cost components are collected for the 'current' period (e.g. from an interview with a respondent). Costs that may have risen, especially in response to rent control or increasing interest rates, may then be linked to income levels, which in practice are not the twins they are made out to be.

A second methodological issue distinguishes the needs of housing studies from those of poverty studies: not all components of cost or overburden can be separated from each other. In housing studies it would be useful to be able to separate out housing costs in a 'narrow' sense referring to rent or mortgage costs (possibly including maintenance costs, insurances and taxes) from housing energy costs. It is also impossible to separate out income problems (income being 'too low') from these 'housing cost' problems ('housing costs' being 'too high') using the at-risk-of-poverty rate, which is the EU-SILC key component measuring income poverty. The at-risk-of-poverty rate is expressed relative to a country's income (see note 2) and does not show whether people have insufficient disposable income to be able to buy a basket of goods and services that is considered minimally essential in order to participate in society (Atkinson et al., 2010; Bradshaw and Mayhew, 2010, 2011; Fusco et al., 2010).

Not only the wish to distinguish between these different types of affordability problem (which type of problem: cost or income?), makes that housing researchers generally are interested in separating out different cost components, but also the desire to clarify the effects of government intervention on the affordability of housing. Except for the impact of 'housing benefits', the effects of other government instruments, such as the favourable tax treatment of the homeowner in income tax, cannot be distilled from each other (Haffner et al., 2012a, b). Furthermore, any subject (person) subsidies for housing that are incorporated into social support cannot be distinguished from other income. Germany is a well-known example of this problem.

\footnotetext{
8 http://ec.europa.eu/eurostat/tgm/table.do?tab=table\&init=1\&language=en\&pcode=tessi160\&plugin=1 (1 November 2015). See the definition of housing costs by tenure: http://ec.europa.eu/eurostat/documents/1012329/6070906/Household+data++housing+data\%2Bchange+in+HH071.pdf/087d4911-ec67-4caf-802a-6ad442b7c012 (1 November 2015).
} 
Nor is it always possible to separate out the effects of lower rents in the social sector compared to market rents, as the EU-SILC does not distinguish social renting from private/commercial renting. Rather it defines the rental sector consisting of the segment where tenants are 'paying rent at prevailing or market rate' on the one hand, and the segment where tenants are renting at a lower-than-market rent, on the other. The instructions are that if this distinction is not clear, dwellings should be classified according to the first category (market rent). As an example, in the Netherlands, this decision results in a classification which, from a housing research perspective, can be regarded as questionable. The Netherlands has the biggest social rental sector in Europe. Furthermore, rents in the rental sector are regulated in more than $90 \%$ of the rental sector, regardless of who owns the dwelling. Based on this knowledge, one would expect, that part of the rental sector would be classified as renting with a'lower-than-market rent', while EU-SILC classifies all Dutch rental dwellings as those where tenants pay market rents. ${ }^{9}$ However, a couple of years ago it has been estimated that, if all subsidies were removed, market rents would be almost twice the current amounts (Romijn and Besseling, 2008). With fallen house prices since 2008, nowadays this calculation may deliver a different outcome, must be observed.

\section{Conceptual issues}

Conceptually, defining affordability is complicated. This can largely be demonstrated by the difference between a tenant and an owner-occupier: the owner-occupier is also an investor, who bears the risk of the investment, which is compensated for with a return. The user cost of capital is a helpful concept here. It allows to calculate the relationship between the return and the imputed rent. The latter is the rent which is imputed that an occupier of an owneroccupied dwelling pays (fictitiously) to the owner by analogy with the rent that the tenant as occupier pays to the landlord as owner of the dwelling (Gardiner et al., 1995). Törmälehto and Sauli (2010: 59-60) conclude that the difficulty in estimating imputed rent (and its components, which are also observed in the EU-SILC) provides room for testing alternative measures, such as cash disposable income after housing costs.

This latter concept is a well-known concept in housing affordability research and is also called residual income - the income that is left over for other consumption necessary for participating in a society after paying for housing (Hancock, 1993). The main advantage of the concept of residual income is that it expresses the absolute minimum necessary level of consumption in a society. In contrast, the EU-SILC cost burden ratio is a relative measure relative to income. It shows people in households in which housing costs account for more than $40 \%$ of their income. They are assumed to be at risk of unaffordability, but, as with the at-risk-of-poverty rate, the percentage is arbitrary, and people with a higher income can probably easily pay these housing costs, while those whose income is lower might have more difficulty, but this is not conveyed by the housing cost burden.

The absolute level of consumption expenditure can be empirically determined for each household type as the amounts spent on a basket of consumption items of a certain quality. Comparing these amounts with the budgets or norm amounts ${ }^{10}$ that are considered necessary

\footnotetext{
${ }^{9}$ That it is difficult to define social renting in statistics is shown by the fact that, not only in the Netherlands, but also in other countries (England for example) social landlords operate in private rental market as well, while statistics are based on dwelling ownership.

${ }^{10}$ Although such norms will be partly subjective, they can be established and validated for a given type of society and adapted in time.
} 
to spend on those items in a country will clarify whether the consumption basket can be considered affordable. This type of approach would be called an absolute one, as opposed to the relative one, where the norm is developed on the basis of a country's income, as is the case with the at-risk-of-poverty rate. Bradshaw and Mayhew (2010, 2011; see also Fusco et al., 2010) tested an approach along these lines and concluded that an indicator based on a budget threshold and used in combination with deprivation measures (such as overcrowding) can have added value in measuring poverty. This type of approach also may have added value in the evaluation of household housing costs.

\section{Making do with what we have}

In this Briefing Paper I attempted to outline a selection of dilemmas (based on the literature) that housing researchers encounter when using the EU-SILC for analyses in the field of housing. Given that EU-SILC is the database for conducting social science research in Europe, we need to make do with what we have, but should do so carefully and transparently. Nevertheless, it may be useful to further explore the development of norms relevant to the context and culture in a country. This may entail a comparison of the housing outcomes for those households that are considered poor and non-poor in country instead of universally ranking countries from high (most problematic) to low (least problematic). 


\section{References}

Atkinson, A. B., E. Marlier, F. Montaigne \& A. Reinstadler 2010. Income poverty and income inequality, Pp. 101-131 in: Atkinson, A. B., E. Marlier (eds.) Income and Living Conditions in Europe. Luxembourg: Publications Office of the European Union.

Bradshaw, J. \& E. Mayhew 2010. Understanding Extreme Poverty in the European Union. European Journal of Homelessness, 4(December): 171-186.

Bradshaw, J. \& E. Mayhew 2011. The Measurement of Extreme Poverty in the European Union. Brussels: European Commission, DG Employment, Social Affairs and Inclusion.

Burns, L. S. \& L. Grebler 1977. The Housing of Nations: Analysis and Policy in a Comparative Framework. London: MacMillan.

European Commission 2009. Portfolio of Indicators for the Monitoring of the European Strategy for Social Protection and Social Inclusion - 2009 Update. September 2009 Update. Brussels: European Commission.

European Council 2010. European Council 17 June 2010: Conclusions. Brussels: European Council.

Fusco, A., A. C. Guio \& E. Marlier 2010. Income poverty and material deprivation in European countries. Eurostat/European Commission.

Gardiner, K., Hills, J., Falkingham, J., Lechene, V. \& H. Sutherland 1995. The Effects of Differences in Housing and Health Care Systems on International Comparisons of Income Distribution. Discussion Paper WSP/10, London, Suntory-Toyota International Centre for Economics and Related Disciplines, London School of Economics.

Haffner, M. \& Kees Dol 2011. Internationale vergelijking van woonuitgaven met EU-SILC. Delft: TU Delft, Onderzoeksinstituut OTB.

Haffner, M. E. A. \& M. Ras 2015. Housing. Pp. 187-219 in Goderis, B. (ed.). Public sector achievement in 36 countries. A comparative assessment of inputs, outputs and outcomes. The Hague: The Netherlands Institute for Social Research/SCP.

Haffner, M., Ch. Lennartz \& Kees Dol 2012a. Measuring housing performance - Is a composite indicator a useful instrument? Delft: Delft University of Technology, OTB Working Paper 2012-08.

Haffner, M., Ch. Lennartz \& Kees Dol 2012b. Housing. Pp. 241-285 in Jonker, Jedid-Jah (ed.). Countries compared on public performance. The Hague and New Brunswick (USA): The Netherlands Institute for Social Research/SCP and Transaction Publishers.

Hancock, K. E. 1993. 'Can Pay? Won't Pay?' or Economic Principles of 'Affordability'. Urban Studies 30 (1): 127-145. DOI: 10.1080/00420989320080081. 
Iacovou, M., O. Kaminska \& H. Levy 2015. Using EU-SILC data for cross-national analysis: strengths, problems and recommendations. s.1., Institute for Social \& Economic Research.

Krell, K., J. R. Frick \& M. M. Grabka 2015. Measuring the consistency of cross-sectional and longitudinal income information in EU-SILC. The Review of Income and Wealth. Early View. DOI: 10.1111/roiw.12202.

Mayo, S. K., S. Malpezzi \& D. J. Gross 1986. Shelter strategies for the urban poor in developing countries. Research Observer 1 (2): 183-203.

Palvarani, P. \& E. Pavolini 2010. Housing Deprivation and Vulnerability in Western Europe, Pp. 126-158 in Ranci, C. (ed.) Social Vulnerability in Europe. The New Configuration of Social Risks. Hampshire, UK, Palgrave Macmillan.

Romijn, G. \& P. Besseling 2008. Economische effecten van regulering en subsidiëring van de huurwoningmarkt. Den Haag: CPB.

Sunega, P. 2014. Subjective or objective? What matters? Critical Housing Analysis 1 (1): 3543. DOI: $10.13060 / 23362839.2014 .1 .1 .28$.

Törmälehto, V.M. \& H. Sauli 2010. The distributional impact of imputed rent in EU-SILC. Luxembourg: EU.

Tunstall, R., M. Bevan, J. Bradshaw, K. Croucher, S. Duffy, C. Hunter, A. Jones, J. Rugg, A. Wallace and S. Wilcox 2013. The links between housing and poverty: An evidence review. York: Joseph Rowntree Foundation. 